\title{
POTENSI PENDIRIAN BMT DI KECAMATAN SUNGAI AUR KABUPATEN PASAMAN BARAT
}

\author{
Oleh: Ahmad Wira* \& Septia \\ Fakultas Syariah IAIN Imam Bonjol Padang \\ J1. M. Yunus Lubuk Lintah \\ e-mail:wira_ukm@yahoo.com
}

\begin{abstract}
Sungai Aur (Sumatera Barat) has its own values and tradition that promote the spirit of togetherness in any aspects of life. These, in turn, will encourage the growth and development of Islamic financial institutions in this region well. The data were analyzed by employing descriptive and SWOT analyses methods. Descriptive analysis was conducted by describing the result of the survey gathered through questionnaire while the SWOT one dealt with analyzing both internal and external conditions of the organization as the basis for designing strategies and work. plans. From those analyses it can be figured out those which were potentially strengths, weaknesses, opportunities and threats of the region.
\end{abstract}

Kata kunci: potensi, BMT, Sungai Aur

\section{PENDAHULUAN}

K ehadiran BMT secara rasional sangat dibutuhkan masyarakat, mengingat sebagian besar masyarakat khususnya di tanah air menjadi pelaku usaha yang bergerak pada sektor usaha mikro. Keberadaan BMT diharapkan dapat memberikan kontribusi yang nyata dalam pengembangan ekonomi. Terlebih bagi kegiatan usaha yang belum memenuhi segala persyaratan untuk mendapatkan pembiayaan dari lembaga perbankan. (Norvadewi, http://daneprairie/mazahib dan http://www.etd.eprints.ums. ac.id/ 5051/1/C100000334.pdf/diakses 08 Juli 2014)

BMT selaku lembaga keuangan mikro syariah menjadi salah suatu alat yang efektif dalam mengatasi kemiskinan. Karena tujuan keberadaan BMT untuk meningkatkan kesejahteraan ekonomi masyarakat dan mengurangi kemiskinan dengan usaha memberikan produk-produknya kepada masyarakat (Muhammad, 2000: 113). Eksistensi BMT jelas memiliki arti penting bagi pembangunan ekonomi syariah serta menjadi inti kekuatan ekonomi yang berbasis kerakyatan dan sekaligus menjadi penyangga utama sistem perekonomian nasional, karena lembaga ini lahir dari rakyat dan untuk rakyat (Harsoyo, http:/ / www.uii.ac. $\mathrm{id} /$ content/view/2868/257/ ?lang=i d/, diakses 06/ 09/2014/ 13.59 WIB). Untuk mewujudkan peran BMT dalam perekonomian tersebut diperlukan peranan pemerintah yang

* Penulis adalah dosen pada IAIN Imam Bonjol Padang 
intensif terhadap eksistensi BMT itu sendiri. Disamping itu juga, perlu adanya dukungan dari masyarakat khususnya umat Islam. Dengan tujuan untuk mengembangkan BMT tersebut, baik dari segi permodalan maupun peningkatan kualitas sumber daya manusianya (SDM).

Karena pendirian dan pengembangan BMT dipengaruhi oleh potensi yang ada pada masyarakat. Potensi tersebut merupakan salah satu modal bagi BMT untuk dapat menarik masyarakat menjadi nasabahnya. BMT sebagai mitra bagi masyarakat tentunya memiliki hubungan yang erat dengan keadaan masyarakat tersebut. Oleh karena itu, perlu dukungan dari berbagai pihak untuk mengembangkan BMT seperti: Para hartawan, pemerintahan, ulama, tokoh masyarakat serta masyarakat sendiri, agar dapat bersatu untuk membantu BMT. Sehingga pemberdayaan ekonomi umat, pengentasan kemiskinan, kesenjangan sosial dapat berkurang sehingga tercapainya keadilan ekonomi, kemakmuran dan kesejahteraan masyarakat dan terlebih tidak kalah pentingnya masyarakat miskin terbebas dari jeratan rentenir.

Berbicara mengenai lembaga keuangan syariah, di Sungai Aur salah satu kecamatan yang ada di Kabupaten Pasaman Barat Propinsi Sumatera Barat, belum mempunyai satupun lembaga keuangan yang berbasis syariah. Padahal kita ketahui Sumatera Barat (Minang Kabau) mempunyai falsafah dasar "adat bersandi syarak, syarak basandi kitabullah (adat bersendi agama, agama bersendi kitabullah) merupakan cermin sikap hidup bahwa agama merupakan pedoman dasar masyarakat. Meskipun kecamatan ini masih baru (11 tahun) dan cukup jauh (41 KM) dari pusat kabupaten namun disisi lain, kecamatan ini mempunyai potensi besar dalam perkebunan sawit. Ini ditandai dengan berdirinya tiga perusahaan besar yang beroperasi. Meskipun sebagian besar dikuasai swasta karena, 21.990 (ha) milik swasta sedangkan milik rakyat hanya 13.158 (ha).

Kecamatan ini juga mempunyai masyarakat yang terbuka karena dalam kecamatan ini terdapat tiga etnis besar yaitu: Jawa, Minang, dan Batak. Sejauh ini masyarakat terhindar dari konflik SARA. Ini disebabkan daerah Sungai Aur (Sumatera Barat) memiliki adat mengutamakan nilai-nilai kebersa-maan dengan prinsip kegotong-royongan dengan dasar berat sama dipikul ringan sama dijinjing. Atas dasar falsafah dan nilai-nilai yang dimiliki oleh masyarakat tersebut maka diperkirakan lembaga keuangan syariah dapat berkembang dengan baik di kecamatan ini.

\section{METODE PENELITIAN}

\section{Lokasi dan Waktu Penelitian}

Penulis melakukan penelitian di kecamatan Sungai Aur, salah satu kecamatan yang ada di Pasaman Barat. Kecamatan ini terdiri dari 22 jorong diantaranya; Sikilang, Kasiak Putih, Sungai Talang, Kumpulan, Sakato Jaya, Lubuk Juangan, Air Haji, Koto Dalam, Bukit Harapan, PT. BPP Sungai Aur, Sungai Aur, Padang Timbalun, Tambang hilir, Situmang, 
Muara Tapus, Pematang Sontang, Simpang Gadang, Sarasah Talang, Sarasah Betung, Bayang Tengah, Sopo Bawak, dan Bukit Melintang.

\section{Teknik Penarikan Sampel}

Populasi dalam penelitian ini adalah semua masyarakat kecamatan Sungai Aur yang terdiri dari 22 jorong. Dalam penelitian ini penulis hanya mengambil 36\% (delapan jorong) dari populasi untuk dijadikan objek penelitian, ini disebabkan lokasi ini sudah bisa mewakili semua daerah penelitian serta kesanggupan dari penulis sendiri. Adapun metode penulis dalam menentukan kedelapan jorong tersebut dengan memilih pusat kecamatan, jorong yang jauh dari kecamatan atau terpencil, yang mempunyai penduduk yang padat, yang mempunyai koperasi dan jorong mempunyai penduduk sedikit. Dari delapan jorong yang menjadi objek penelitian tersebut diantaranya: Air Haji, Sungai Aua, Padang Timbalun, Situmang, Tambang Hilir, Muara Tapus, Pematang Sontang, dan Simpang Gadang. Jumlah penduduk dari kedelapan jorong ini sebanyak 11.962 jiwa.

Dalam penelitian ini, teknik penarikan jumlah sampel untuk mewakili populasi ditentukan dengan menggunakan rumus Slovin (Buchari, 2007: 35), yaitu:

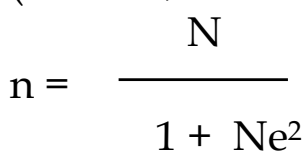

Keterangan :

$\mathrm{n}=$ Number of sample (jumlah sampel).
$N=$ Total population (jumlah seluruh anggota populasi).

$e=$ Error tolerance (toleransi terjadinya galat; taraf signifikansi; persen kelonggaran ketidaktelitian karena kesalahan pengambilan sampel).

Maka berdasarkan rumus Slovin tersebut, dengan kelonggaran sampel sebesar $10 \%$ dapat diketahui jumlah sampel yang akan diambil dari jumlah penduduk yang terdapat di kecamatan Sungai Aur, sebagai berikut;

$$
n=\frac{11.962}{1+11.962(0,1)^{2}}
$$

= 99,171 jika dibulatkan menjadi 99

Jadi, jumlah sampel dalam penelitian ini sebanyak 99 responden. Pengambilan jumlah sampel pada masing-masing jorong (desa) ditentukan dengan memakai rumusan alokasi proportional kemudian dicari sampel berstrata dari masing-masing jorong dengan rumus: $n_{i}=\left(N_{i}: N\right)$. $\mathrm{n}$

a. Jorong Air Haji = $2831: 11.962 \times$ $99,171=23,349 \longrightarrow 24$

b. Jorong Sungai Aur = 1869 : $11.962 \times 99,171=14,385 \longrightarrow 14$

c. Jorong Padang Timbalun $=816$ : $11.962 \times 99,171=6,410 \longrightarrow 6$

d. Jorong Situmang $=516: 11.962 \times$ $99,171=4,246 \longrightarrow 4$

e. Jorong Tambang Hilir $=807$ : $11.962 \times 99,171=6,830 \longrightarrow 7$

f. Jorong Muara Tapus $=958$ : $1.962 \times 99,171=7,750 \longrightarrow 8$

g. Jorong Pematang Sontang $=2143$ : $11.962 \times 99,171=17,471 \longrightarrow 18$

h. Jorong Simpang Gadang $=2022$ : $11.962 \times 99,171=17,487 \longrightarrow 18$ Jadi, total sampel adalah 99 . 
Pengambilan sampel yang akan diteliti ditentukan dengan sampling purposive. Sampling purposive merupakan teknik penentuan sampel dengan pertimbangan (Sugiyono, 2009: 120). Maka penentuan sampel pada penelitian ini dipilih yang memiliki kriteria: (Ulber Silalahi, 2010: 30)

a. Umur 17 sampai dengan 55 tahun.

b. Sudah mempunyai pekerjaan.

c. Bekerja di tempat penelitian.

d. Bertempat tinggal di wilayah penelitian.

\section{Teknik Analisis}

\section{Analisis Deskriptif}

Analisis data dilakukan dengan metode analisis deskriptif yang dilakukan dengan mendeskripsikan hasil survei yang diperoleh menggunakan kuisioner (Ferddy Rangkuty, 2013: 25). Dalam penelitian ini analisis deskriptif kualitatif berupa tabel, grafik, maupun diagram dimana tabel, grafik dan diagram tersebut menggunakan distribusi persentase dan nominal.

\section{Analisis SWOT}

Analisis SWOT adalah analisis kondisi internal maupun eksternal suatu organisasi yang selanjutnya akan digunakan sebagai dasar untuk merancang strategi dan program kerja. Analisis internal meliputi penilaian terhadap faktor kekuatan (strength) dan kelemahan (weakness). Sementara, analisis eksternal mencakup faktor peluang (opportunity) dan tantangan (threaths) (Ferddy Rangkuty, 2013: 25).

Sebelum membuat matriks strategi eksternal, kita perlu mengetahui terlebih dahulu faktor strategi eks- ternal. Berikut cara penentuan faktor strategi eksternal:

a) Susunlah dalam kolom 1 (peluang dan ancaman)

b) Beri bobot masing-masing faktor dalam kolom 2, mulai dari 1,00 (Sangat Penting), sampai 0,00 (Tidak Penting) faktor-faktor tersebut kemungkinan dapat memberikan dampak terhadap faktor strategis.

c) Hitunglah rating (dalam kolom 3) untuk masing-masing faktor memberikan skala mulai dari 4 (sangat penting) sampai dengan 1 (tidak penting). Pemberian nilai rating terhadap peluang bersifat positif (peluang semakin besar diberi rating +4 , tetapi peluangnya kecil diberi rating +1). Pemberian rating ancamannya sangat besar, ratingnya adalah 1 . Sebaliknya, jika nilai ancamannya sedikit ratingnya 4 .

d) Kalikan bobot pada kolom 2 dengan rating pada kolom 3, untuk memperoleh faktor pembobotan dalam kolom 4 .

e) Gunakan kolom 5 untuk memberikan komentar atau catatan mengapa faktor-faktor tertentu dipilih dan bagaimana skor pembobotannya dihitung.

f) Jumlahkan (pada kolom 4), untuk memperoleh total skor pembobotan bagi perusahaan yang bersangkutan. Nilai total ini menunjukkan bagaimana perusahaan tertentu beraksi terhadap faktor-faktor strategi eksternalnya. Total skor ini dapat digunakan untuk membandingkan perusahaan ini dengan perusahaan lainnya dalam kelompok industri yang sama. 
Jika telah menyelesaikan analisis faktor-faktor strategi eksternalnya (peluang dan ancaman) maka langkah selanjutnya adalah menganalisis faktor strategi internal (kekuatan dan kelemahan) dengan cara yang sama.

Setelah indikator-indikator SWOT ditentukan, langkah pertama adalah bobot, rating, skor (Ferddy Rangkuty, 2013: 36-37). Bobot ditentukan berdasarkan tingkat kepentingan.

Langkah kedua adalah menjumlahkan bobot kekuatan dan kelemahan. Kemudian dihitung untuk masing-masing indikator yang terdapat pada kekuatan dan kelemahan, sehingga total bobot tersebut menjadi 1 atau $100 \%$. Dengan cara yang sama dihitung bobot dan bobot relatif untuk peluang dan ancaman.

Langkah ketiga adalah menentukan rating. Rating adalah analisis kita terhadap kemungkinan yang akan terjadi dalam jangka pendek (misalnya satu tahun ke depan). Nilai variabel untuk kekuatan diberi nilai 1 sampai 4. Diberi nilai 1 kalau kemungkinan indikator tersebut kinerja semakin menurun dibanding pesaing utama. Diberi nilai 2 indikator jika indikator itu kinerjanya sama dengan pesaing utama. Sedangkan nilai 3 atau 4, jika indikator tersebut lebih baik dibandingkan pesiang utama. Semakin tinggi nilainya artinya kinerja indikator tersebut semakin baik dibandingkan pesaing utama.

Nilai variabel kelemahan diberi nilai 1 sampai 4 . Nilai 1 jika indikator tersebut semakin banyak kelemahannya dibandingkan pesaing utama.
Sebaliknya nilai diberi nilai 4 jika kelemahan indikator tersebut semakin menurun dibandingkan pesaing utama. Artinya pemberian rating untuk variable kelemahan atau ancaman berkebalikan dengan nilai rating untuk variabel kekuatan dan peluang.

Nilai skor diperoleh berdasarkan hasil nilai pembobotan dikali nilai rating. Total nilai skor untuk faktor menunjukkan bahwa nilainya mendekati 1, semakin banyak kelemahan internal dibandingkan kekuatannya. Sedangkan semakin mendekati nilai 4, semakin banyak kekuatannya dibandingkan kelemahannya.

Begitu juga dengan total untuk factor eksternal. Nilai skor yang mendekati 1, ancamannya lebih banyak dibandingkan dengan peluangnya. Sebaliknya apabila skor-nya mendekati 4, maka peluangnya lebih besar disbandingkan ancaman-nya.

Gabungan keduanya kondisi internal dan eksternal ini selanjutnya kita masukkan dalam internal external matrik, sehingga kita mengetahui posisi persaingan yang akan terjadi pada produk yang kita analisis. Bedasarkan posisi ini kita dapat menentukan strategi yang tepat untuk menentukan memenangkan persaingan.

Sedangkan untuk menentukan titik sumbu $x$ dan $y$, kita melakukan pengurangan antara jumlah total faktor $\mathrm{S}$ dengan $\mathrm{W}$ (a) dan faktor $\mathrm{O}$ dengan $\mathrm{T}(\mathrm{b})$; Perolehan angka $(\mathrm{a}=\mathrm{x})$ selanjutnya menjadi nilai atau titik pada sumbu $X$, sementara perolehan angka $(b=y)$ selanjutnya menjadi nilai atau titik pada sumbu $Y$. 


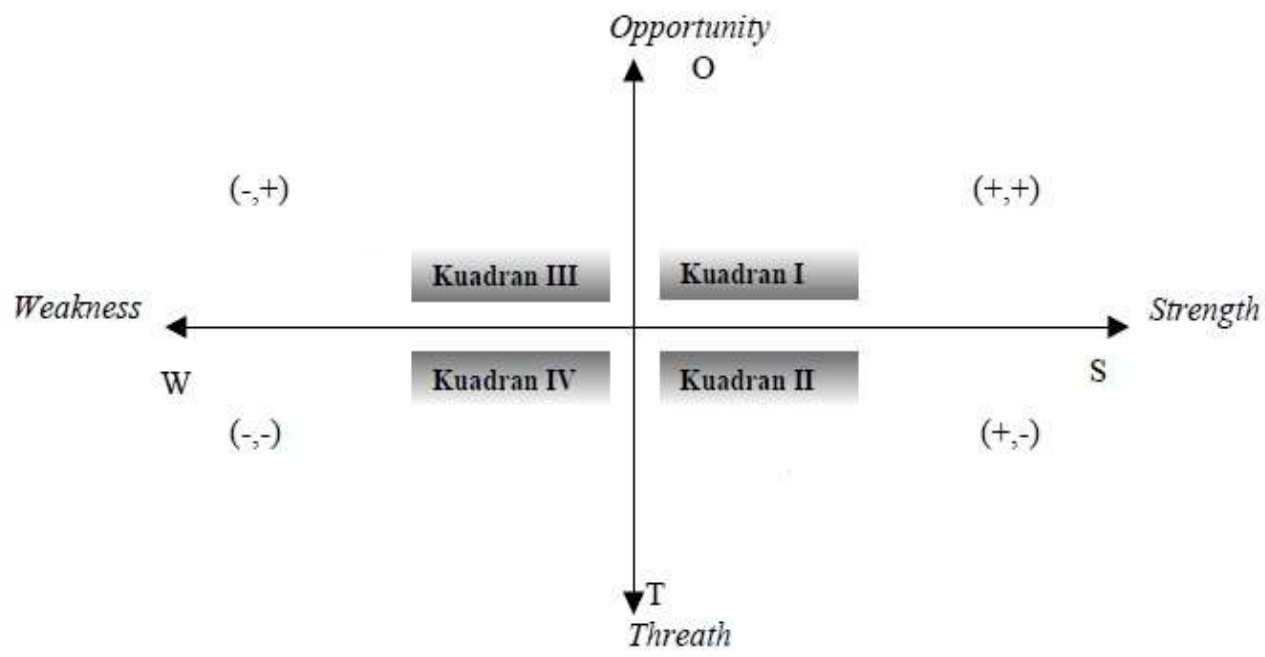

\section{Gambar 1 Matriks Kuadran SWOT}

Dari Gambar 1 di atas dapat diketahui bagaimana Matriks kuadran SWOT yang dapat dijelaskan sebagai berikut:

1. Kuadran I (positif, positif)

Posisi ini menandakan sebuah organisasi yang kuat dan berpeluang. Rekomendasi strategi yang diberikan adalah Progresif, artinya organisasi dalam kondisi prima dan mantap sehingga sangat dimungkinkan untuk terus melakukan ekspansi, memperbesar pertumbuhan dan meraih kemajuan secara maksimal.

2. Kuadran II (positif, negatif)

Posisi ini menandakan sebuah organisasi yang kuat namun menghadapi tantangan yang besar. Rekomendasi strategi yang diberikan adalah Diversifikasi Strategi, artinya organisasi dalam kondisi mantap namun menghadapi sejumlah tantangan berat sehingga diperkirakan roda organisasi akan mengalami kesulitan untuk terus berputar bila hanya bertumpu pada strategi sebelumnya. Oleh karenanya, organisasi disarankan untuk segera memperbanyak ragam strategi taktisnya.

3. Kuadran III (negatif, positif)

Posisi ini menandakan sebuah organisasi yang lemah namun sangat berpeluang. Rekomendasi strategi yang diberikan adalah Ubah Strategi, artinya organisasi disarankan untuk mengubah strategi sebelumnya. Sebab, strategi yang lama dikhawatirkan sulit untuk dapat menangkap peluang yang ada sekaligus memperbaiki kinerja organisasi.

4. Kuadran IV (negatif, negatif)

Posisi ini menandakan sebuah organisasi yang lemah dan menghadapi tantangan besar. Rekomendasi strategi yang diberikan adalah Strategi Bertahan, artinya kondisi internal organisasi berada pada pilihan dilematis. Oleh karenanya organisasi disarankan untuk menggunakan strategi ber- 
tahan, mengendalikan kinerja internal agar tidak semakin terperosok. Strategi ini dipertahankan sambil terus berupaya membenahi diri.

\section{HASIL PENELITIAN}

\section{Analisis SWOT Potensi Masyarakat terhadap Pendirian BMT di Keca- matan Sungai Aur}

Untuk dapat melihat dan menilai berpotensi atau tidaknya masyarakat terhadap pendirian BMT di Kecamatan Sungai Aur dilakukan analisis internal dan eksternal dengan menggunakan analisis SWOT. Berdasarkan data yang telah diperoleh maka faktor internal dan eksternal tersebut dapat diidentifikasi dan diuraikan sebagai berikut:

\section{Faktor Internal}

Berdasarkan tinjauan pustaka terhadap BMT maka dapat dirumuskan kekuatan dan kelemahan yang dimiliki oleh BMT. Adapun kekuatan dan kelemahan tersebut adalah:

\section{a. Strengths (Kekuatan)}

1) Proses pendirian mudah

Pendirian BMT dapat didirikan sebagai kelompok swadaya masyarakat, sehingga proses lebih mudah.

2) Membuka kesempatan kerja Pendirian BMT akan membutuhkan tenaga kerja untuk pengelolaan dan pengembangan BMT.

3) Memiliki jangkauan kepada usaha kecil

Sebagai lembaga keuangan mikro $\mathrm{BMT}$, kegiatan BMT memprioritaskan pada masyarakat kalangan bawah.
4) Mandiri dan mudah mengakar di masyarakat

Tidak ada intervensi dari pihak manapun karena lembaga ini lahir dari rakyat dan untuk rakyat. Sehingga keberadaan BMT akan mudah diterima masyarakat.

5) Bentuk organisasi sederhana.

Dalam BMT cukup 20 orang anggota, BMT sudah bisa beroperasi (PINBUK, 2011: t.h.).

b. Weakness (Kelemahan)

1) Belum populer di kalangan Masyarakat

Belum adanya lembaga keuangan syari'ah di daerah penelitian, sehingga BMT menjadi sesuatu yang baru dan belum populer bagi masyarakat.

2) Modal masih terbatas

Lembaga keuangan mikro BMT masih mengalami kekurangan modal, sehingga perlu dicarikan solusi optimal.

3) Skala usaha kecil

BMT salah satu lembaga keuangan mikro jadi skala usahanya kecil dan usaha-usaha yang dapat di tangani juga hanya berskala kecil.

4) Sumber Daya Manusia Masih lemah

Belum banyak orang yang paham dan bisa mengelola BMT tersebut.

5) Sistem dan Prosedur yang mengatur belum baku.

Ini dapat dilihat dari badan hukum yang masih memakai badan hukum koperasi, begitu juga dengan sistem yang mengatur belum ada yang baku. Selama ini BMT hanya dibantu Pusat Inkubasi Bisnis Usaha Kecil (PINBUK) 


\section{Faktor Eksternal}

Berdasarkan pengumpulan data yang telah dilakukan maka diperoleh faktor-faktor yang menjadi peluang dan ancaman terhadap pendirian BMT yaitu:

\section{a. Opportunities (Peluang)}

1) Adanya kebutuhan modal Dari pernyataan narasumber mengakui bahwa mereka masih membutuhkan modal.

2) Jenis pekerjaan masyarakat yang mayoritas sebagai petani dan sektor informal

Jenis pekerjaan utama masyarakat pada sektor pertanian masih membutuhkan pembiayaan agar dapat meningkatkan usaha yang dijalankan.

3) Norma agama dan adat menjadi dasar dalam keluarga

Dengan menjadikan norma agama dan adat yang dijalankan dalam keluarga memungkinkan masyarakat akan tertarik dengan BMT. Serta semakin sering masyarakat mengikuti kegiatan agama maka akan menambah pemahaman agama masyarakat sehingga akan mudah memahami BMT tersebut.

4) Sebagian besar masyarakat masih pada usia yang cukup produktif Pada usia yang masih produktif memungkinkan untuk tetap dapat mengembangkan usaha dan meningkatkan usaha yang dijalankan.

5) Masyarakat Terbuka

Seperti yang telah dijelaskan sebelumnya, bahwa di kecamatan ini terdapat tiga etnis besar yaitu; Jawa, Minang, dan Batak. Akibatnya masyarakat lebih terbuka terhadap hal-hal yang baru. Ini merupakan peluang besar untuk mendirikan BMT di Kecamatan ini.

6) Adanya dukungan masyarakat yang sudah mengetahui tentang BMT. Dari 43 responden 41 orang menyatakan dukungannya dan bersedia menjadi anggota.

\section{b. Threats (Ancaman)}

1) Kurangnya kejujuran sebagian masyarakat

Kejuruan hal yang sangat penting dalam membangun kepercayaan sebuah lembaga keuangan, sehingga hal ini menjadi ancaman berarti dalam operasional BMT nantinya.

2) SDM yang kurang

Meskipun tingkat pendidikan di kecamatan ini cukup baik, namun tidak menjamin memahami BMT tersebut. Karena BMT ini belum begitu terkenal di kalangan masyarakat.

3) Masih banyak masyarakat yang belum mengetahui BMT.

Hanya (43\%) dari total responden yang mengakui mengetahui atau mendengar tentang BMT. Ini menunjukkan bahwa masih banyak masyarakat yang belum mengetahui BMT dan ini akan menjadi ancaman terhadap pendirian BMT tersebut.

4) Potensi menabung kurang

Dari hasil angket menunjukkan bahwa, mayoritas pengeluaran responden per bulannya cukup besar yaitu Rp 1.500.000-2.499.000 dan dari keterangan beberapa narasumber menjelaskan bahwa masyarakat cenderung konsumtif, sehingga belum terbiasa untuk menabung. 
5) Lembaga keuangan pesaing

Adanya lembaga keuangan lain yang beroperasi lebih dulu di daerah penelitian dan sudah memiliki anggota yang cukup banyak.
Berdasarkan hasil tersebut dapat dirangkum faktor internal pada tabel berikut:

Tabel 1

Faktor Internal

\begin{tabular}{|c|c|c|c|c|c|}
\hline No & Faktor Internal & Skor & Bobot & Total & Penilaian \\
\hline \multirow[t]{7}{*}{1} & Strengths (Kekuatan) & & & & \\
\hline & 1) Proses pendirian mudah & 3 & 0.10 & 0.30 & Penting \\
\hline & $\begin{array}{l}\text { 2) Membuka kesempatan ker- } \\
\text { ja }\end{array}$ & 2 & 0.06 & 0.12 & Kurang Penting \\
\hline & $\begin{array}{l}\text { 3) Memiliki jangkauan kepada } \\
\text { pengusaha mikro }\end{array}$ & 4 & 0.20 & 0.80 & Sangat Penting \\
\hline & $\begin{array}{l}\text { 4) Mandiri dan mudah meng- } \\
\text { akar di masyarakat }\end{array}$ & 3 & 0.20 & 0.60 & Penting \\
\hline & $\begin{array}{l}\text { 5) Bentuk organisasi seder- } \\
\text { hana }\end{array}$ & 2 & 0.10 & 0.20 & Kurang Penting \\
\hline & $\begin{array}{l}\text { 6) Prosedur pembiayaan mu- } \\
\text { dah }\end{array}$ & 3 & 0.10 & 0.30 & Penting \\
\hline \multicolumn{4}{|c|}{ Total Strengths (Kekuatan) } & 2.32 & \\
\hline \multirow[t]{6}{*}{2} & Weakness (Kelemahan) & & & & \\
\hline & $\begin{array}{l}\text { 1) Belum populer dikalangan } \\
\text { Masyarakat }\end{array}$ & 3 & 0.08 & 0.24 & Penting \\
\hline & 2) Modal masih terbatas & 4 & 0.10 & 0.40 & Sangat penting \\
\hline & 3) Skala usaha kecil & 2 & 0.7 & 0.14 & Kurang penting \\
\hline & $\begin{array}{l}\text { 4) Sumber daya manusia } \\
\text { (SDM) lemah }\end{array}$ & 4 & 0.10 & 0.40 & Sangat penting \\
\hline & $\begin{array}{l}\text { 5) Sistem dan Prosedur belum } \\
\text { baku }\end{array}$ & 2 & 0.07 & 0.14 & Kurang Penting \\
\hline \multicolumn{4}{|c|}{ Total Weakness (Kelemahan) } & 1.32 & \\
\hline
\end{tabular}

Selisih total $=>S-W=2.32-1.32=1=x$ 
Faktor eksternal disajikan pada tabel 2

Tabel 2

Faktor Eksternal

\begin{tabular}{|c|c|c|c|c|c|}
\hline No & Faktor Eksternal & Skor & Bobot & Total & Penilaian \\
\hline \multirow[t]{7}{*}{1} & Opportunities (Peluang) & & & & \\
\hline & $\begin{array}{l}\text { 1) Adanya kebutuhan modal } \\
\text { 2) Jenis pekerjaan masyarakat }\end{array}$ & 4 & 0.20 & 0.80 & Sangat penting \\
\hline & $\begin{array}{l}\text { yang mayoritas sebagai } \\
\text { petani dan sektor informal }\end{array}$ & 3 & 0.07 & 0.21 & Penting \\
\hline & $\begin{array}{l}\text { 3) Norma agama dan adat } \\
\text { menjadi dasar dalam keluar- } \\
\text { ga }\end{array}$ & 2 & 0.06 & 0.12 & Kurang penting \\
\hline & $\begin{array}{l}\text { 4) Sebagian besar masyarakat } \\
\text { masih pada usia yang cukup } \\
\text { produktif }\end{array}$ & 3 & 0.06 & 0.18 & Penting \\
\hline & $\begin{array}{l}\text { 5) Adanya dukungan masya- } \\
\text { rakat yang sudah menge- } \\
\text { tahui tentang BMT }\end{array}$ & 4 & 0.20 & 0.80 & Sangat penting \\
\hline & 6) Masyarakat terbuka & 3 & 0.09 & 0.27 & Penting \\
\hline \multicolumn{4}{|c|}{ Total Opportunities (Peluang) } & 2.38 & \\
\hline \multirow[t]{7}{*}{2} & Threats (Ancaman) & & & & \\
\hline & $\begin{array}{l}\text { 1) Kurangnya kejujuran seba- } \\
\text { gian masyarakat }\end{array}$ & 4 & 0,06 & 0.24 & Sangat Penting \\
\hline & 2) SDM masih kurang & 4 & 0.10 & 0.40 & Sangat penting \\
\hline & $\begin{array}{l}\text { 3) Masih banyak masyarakat } \\
\text { yang belum mengetahui }\end{array}$ & & & & \\
\hline & BMT & 3 & 0.07 & 0.21 & Pentir \\
\hline & 4) Potensi menabung kurang & 4 & 0.09 & 0.36 & Sangat penting \\
\hline & 5) Lembaga keuangan pesaing & 4 & 0.10 & 0.40 & Sangat penting \\
\hline \multicolumn{2}{|c|}{ Total Threats (Ancaman) } & & & 1.61 & \\
\hline \multicolumn{5}{|c|}{ Selisih total $=>0-\mathrm{T}=2.38-1.65=0.77=\mathrm{y}$} & \\
\hline
\end{tabular}

Untuk melihat posisi potensi dari analisis SWOT terdapat pada gambar 2 


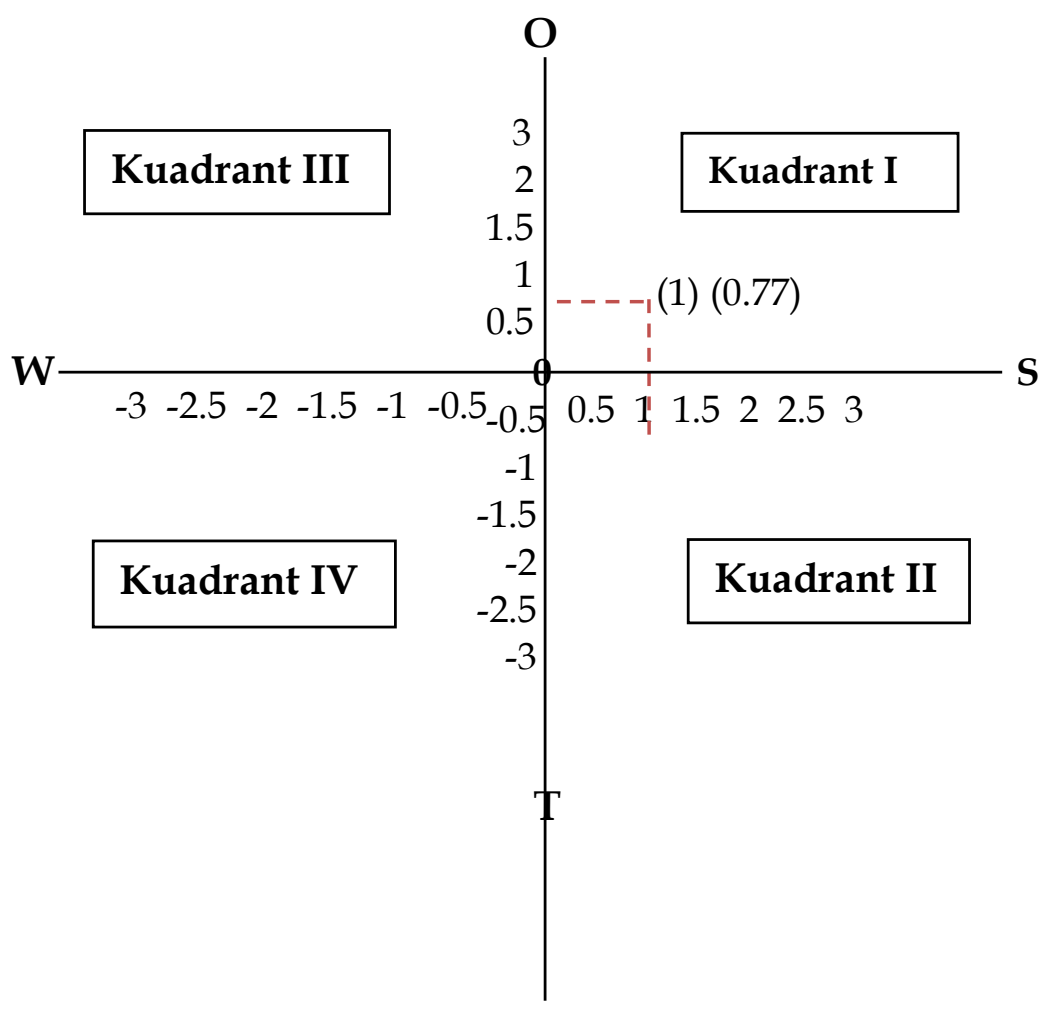

\section{Gambar 2 \\ Matriks Kuadrant SWOT}

Dari gambar 2 dapat diketahui bahwa posisi pendirian BMT dengan potensi mayarakat yang ada berada pada kuadrant I sehingga dapat dijelaskan bahwa pada posisi ini menandakan sebuah organisasi yang kuat dan berpeluang, rekomendasi strategi yang diberikan adalah Progresif, masyarakat memiliki potensi sehingga sangat dimungkinkan untuk melakukan pendirian BMT di daerah penelitian ini.

\section{PENUTUP}

\section{Kesimpulan}

Dari hasil penelitian potensi masyarakat dalam pendirian BMT di kecamatan Sungai Aur Kabupaten Pasaman Barat dapat disimpulkan bahwa:

Dari hasil analisis deskriptif dapat diketahui beberapa potensi masyarakat yang dapat menjadi peluang dan ancaman terhadap pendirian BMT. Sedangkan hasil dari analisis SWOT Penilaian terhadap Faktor Internal kekuatan dan kelemahan yang dimiliki oleh BMT secara umum menunjukkan hasil yang positif yaitu terdapat selisih antara kekuatan dan kelemahan yang dimiliki BMT sebesar 1 Sedangkan dari faktor eksternal diketahui bahwa terdapat selisih total penilaian antara peluang dan ancaman yaitu sebesar 0,77 . Sehingga dapat diketahui dari 
matriks kuadran SWOT bahwa posisi BMT berada pada kuadran I. Posisi ini menandakan bahwa BMT yang akan didirikan mempunyai kekuatan dan berpeluang. Sehingga sangat memungkinkan untuk mendirikan BMT di tempat penelitian.

\section{Saran}

Berdasarkan pembahasan dan kesimpulan di atas maka beberapa saran yang dapat penulis berikan adalah:

1. Masyarakat masih banyak yang belum mengetahui tentang BMT, hanya $(43 \%)$ dari total responden yang mengaku mengetahui atau mendengar tentang BMT. Ini menunjukkan bahwa, di daerah

\section{DAFTAR PUSTAKA}

Buchari. 2007. Belajar mudah Penelitian Untuk Guru, Karyawan, Peneliti Pemula. Bandung: AlFabeta.

Harsoyo, 2014. Makalah disajikan dalam Seminar Nasional, BMT Di Awasi? Siapa Takut! Ruang Lingkupan Pengawasan OJK Terhadap Lembaga Keungan Mikro syariah, Universitas Islam Indonesia: Rabu 11 Juni 2014, (http://www.uii.ac.id/ content/view/ 2868/257/?lang =id/Diakses 06/09/2014/ 13.59)

Muhammad. 2000. Lembaga Keuangan Umat Kontemporer. Yogyakarta: UII Pres.

Nasution, Alwi Reza. 2006. Analisis Potensi dan Preferensi Terhadap Bank Syari'ah di Wilayah Kota penelitian masih dibutuhkan upaya sosialisasi yang lebih intensif terhadap pengenalan BMT sehingga masyarakat lebih mengetahui dan memahami mengenai BMT.

2. Berdasarkan analisis SWOT menunjukkan bahwa matriks berada pada kuadran I ini berarti, bagi pihak-pihak yang ingin mendirikan BMT di daerah penelitian sangat bagus.

3. Bagi pemerintah, perlu adanya perhatian lebih serius terhadap BMT. Karena BMT bisa menjadi salah satu alternatif untuk memberantas kemiskinan.

Medan, Skripsi tidak diterbitkan. Medan.

Norvadewi, "Tinjauan Syariah Terhadap Badan Hukum Koperasi Untuk Baitul Maal Wat Tamwil (BMT)," (http://daneprairie/ mazahib diakses 2007) dan http:// (www.etd.eprints.ums. ac.id/5051/1/C100000334.pdf/ diakses 08/07/ 2014)

Pusat Inkubasi Bisnis Usaha Kecil, Panduan Operasional Manajemen \& Prosedur KJKS. 2011. Jakarta: PINBUK.

Rangkuty, Ferddy. 2013. Analisis SWOT: Teknik Membedah Kasus Bisnis. Jakarta: PT Gremedia Pusat Utama Kompas. 
Silalahi, Ulber. 2010. Metodologi Penelitian Sosial. Bandung: PT. Refika Aditama.
Sugiyono. 2009. Metode Penelitian Bisnis. Bandung: CV. Alfabeta. 